\title{
Piyasada Kişniş Olarak Satılan Örneklerin Avrupa Farmakopesi Kriterleri Yönünden \\ İncelenmesi*
}

\section{An Investigation of the Samples Sold as Coriander in the Market in Terms of the European}

Pharmacopoeia Criteria

Erek Ulutaşi, Semih Buluti, Didem Deliorman Orhan ${ }^{\mathrm{iii}}$

'Ecz., T.C Sağlık Bakanlığı Türkiye İlaç ve Tıbbi Cihaz Kurumu, Bitkisel ve Destek Ürünler Dairesi Başkanlığı https://orcid.org/0000-0002-2949-8100

iArş. Gör., Gazi Üniversitesi Eczacılık Fakültesi Farmakognozi AD., https://orcid.org/0000-0002-4098-0221

iiiProf. Dr., Gazi Üniversitesi Eczacılık Fakültesi Farmakognozi AD., https://orcid.org/0000-0003-3916-4048

öz

Amaç: Kişniş (Coriandrum sativum L.) meyveleri gıda olarak ve tıbbi amaçlarla kullanılmaktadır. Piyasada satılan ve tıbbi amaçlarla kullanılan kişniş meyvelerinin kalite kriterleri hakkında bir bilgi mevcut değildir. Bu sebeple, özellikle karminatif, antispazmotik ve iştah arttırıcı özellikleri sebebiyle sıklıkla kullanılan ve 12 farklı aktardan satın alınan kişniş örneklerinin kalite kontrolleri Avrupa Farmakopesi 8.0 standartlarına göre araştırılmıştır.

Yöntem: Kişniş numunelerinin standartlara uygunluğunu belirlemek için Avrupa Farmakopesi 8.0'da yer alan "Coriandri fructus" monografı kullanılmıştır. Örnekler, monografta belirlenen tüm analizler (morfolojik, mikroskobik, ince tabaka kromatografisi, yabancı madde, total kül, kurutmada kayıp ve uçucu yağ miktar tayini analizleri) için değerlendirilmiştir.

Bulgular: Bütün numunelerin morfolojik, mikroskobik, kurutmada kayıp, ince tabaka kromatografisi ve total kül miktarı analiz sonuçlarının Farmakopeye uygunluk gösterdiği, bir kısım numunenin yabancı madde ve uçucu yağ miktar tayini sonuçlarının Farmakope standartlarına uygunluk göstermediği tespit edilmiştir.

Sonuç: Analiz sonuçlarına göre incelenen 12 numunenin Avrupa Farmakopesi 8.0 standartlarına uygun olmadığı tespit edilmiştir. Bu çalışma ile bu tip bitkisel ürünlerin tıbbi amaçlarla ve fitoterapide kullanılmasının halk sağlığı açısından uygun olmadığı ve bu ürünlerin kalite kontrol analizleri yapıldıktan sonra eczanelerde satılmasının önemi bir kez daha ortaya çıkmıştır.

Anahtar Kelimeler: Apiaceae, Avrupa Farmakopesi, Coriandrum sativum, Fitoterapi, Kişniş

\section{ABSTRACT}

Aim: Coriander (Coriandrum sativum L.) fruits are used as food and for medicinal purposes. There is no information about the quality criteria of coriander fruits sold in the market and used for medicinal purposes. For this reason, quality controls of coriander samples, which are frequently used due to its carminative, antispasmotic and appetite enhancing properties and purchased from 12 different herbalists, have been investigated according to the European Pharmacopoeia 8.0 standards.

Method: "Coriandri fructus" monograph in European Pharmacopoeia 8.0 was used to determine the quality of the Coriander samples. Samples were evaluated for all analyzes (morphological, microscopic, thin layer chromatography, foreign matter, total ash, loss in drying and essential oil quantification analysis) identified in the monograph.

Results: Morphological, microscopic, loss in drying, thin layer chromatography and total ash analysis results of all samples were found to be in accordance with Pharmacopoeia, and foreign matter and essential oil quantification results of some samples did not comply with Pharmacopoeia standards.

Conclusion: According to the results of the analysis, it was determined that the 12 samples examined were not compliant with the European Pharmacopoeia 8.0 standards. With this study, it was once again revealed that the use of these types of herbal products for medicinal purposes and phytotherapy is not suitable for public health and the importance of selling these products in pharmacies after quality control analysis has been made.

Key words: Apiaceae, European Pharmacopoeia, Coriandrum sativum, Phytotherapy, Coriander

"Mersin Üniversitesi Tıp Fakültesi Lokman Hekim Tıp Tarihi ve Folklorik Tıp Dergisi, 2021; 11 (3): $492-501$

DOI: $10.31020 /$ mutftd.916536

e-ISSN: 1309-8004, ISSN 1309-761X

Geliş Tarihi - Received: 15 Nisan 2021; Kabul Tarihi - Accepted: 26 Mayıs 2021

iletişim - Correspondence Author: Didem Deliorman Orhan < didemdeliorman@gmail.com > 


\section{Giriş}

Anavatanı Akdeniz ülkeleri olan Coriandrum sativum L., Apiaceae familyasına ait bir bitki olup, Asya, Rusya, Orta Avrupa ve Kuzey Afrika'da kültürü yapılmaktadır. ${ }^{1}$ En eski kişniş meyveleri İsrail'de bulunan Nahal Hemar Mağarası'nda M.Ö. 6000 yıllarında keşfedilmiştir. Kullanımı hakkındaki ilk bulgular tıbbi amaçla kullanıldığını göstermektedir. Bitkinin, Mısır mezarlarında bulunmasının da mitolojik bir öneme sahip olduğunu göstermektedir. ${ }^{2}$ C. sativum 3000 yıldan fazla süredir kullanılmaktadır. ${ }^{1}$ Türkiye'de Marmara, Güney Doğu Anadolu ve Batı Akdeniz bölgelerinde doğal olarak yetişmektedir. ${ }^{3}$ Ankara, Eskişehir, Konya, Niğde'de $C$. sativum bitkisinin ticari amaçla kültürü yapılmaktadır. ${ }^{4}$ Bitki halk arasında "kişniş, kişnit, kişniç veya yumurca" isimleri ile bilinmektedir. Kişniş meyveleri uçucu yağ içermesi nedeniyle genellikle oral olarak iştahsızlık, gaz, dispepsi, diyare, ağrı ve kusma gibi sindirim sistemi ve mide şikâyetlerinde kullanılmaktadır. Olgunlaşmış meyvelerinden ve yapraklarından baharat olarak ve şekercilikte de faydalanılmaktadır. ${ }^{1,5}$ Olgun meyvelerden distilasyon yöntemi ile elde edilen uçucu yağ farmasötik preparatlarda tatlandırıcı olarak kullanılmıştır.

Kişniş meyvelerinin kimyasal içeriği incelendiğinde miktar olarak en fazla bulunan sekonder metabolit gruplarının uçucu yağ $(\% 0,03-2,60)$ ve sabit yağ $(\% 9,90-27,70)$ olduğu görülmektedir. Yağ içerikleri kültüre alınan bitkiye bağlı olarak değişebilmektedir. Ayrıca meyveler $\% 11,37$ su, $\% 11,49$ protein, $\% 28,43$ lif, $\% 10,53$ nişasta, \%10,29 pentozanlar, \%1,92 şeker ve \%4,98 oranında mineral içermektedir. ${ }^{2}$ Kişniş meyvelerinden elde edilen total lipit ekstresinin bileşiminin büyük bir kısmını nötral lipitlerin $(\% 95,65)$ oluşturduğu tespit edilmiştir. Bu nötral lipitlerin büyük bir kısmını da triaçilgliseroller oluşturmaktadır. Meyvelerde en çok bulunan fosfolipitlerin; fosfotidilkolin ve fosfotidiletanolamin olduğu görülmüştür. ${ }^{6,7}$

C. sativum, birçok ülkede sindirim, solunum ve üriner sistem bozukluklarının yanı sıra diyabet, iltihaplanma, uykusuzluk, anksiyete, konvülsiyon ve diğer durumları tedavi etmek için geleneksel bir ilaç olarak kullanılmaktadır. Kişniş tadı buruk kabul edilir; bütün bitki soğuk algınlığını tedavi etmek için kullanılırken, meyveler genellikle hazımsızlık ve iştahsızı̆ı̆ın tedavisi için kullanılmıştır. C. sativum'daki ana biyoaktif bileşenlerin (uçucu yağ, yağ asitleri, tokol, sterol ve karotenoidler) verimleri ve kimyasal içerikleri genotip, ekim mevsimi, ekotip, ekim durumu, büyüme aşaması, bitki bölümü, hasat zamanı, ayıklama süreci ve diğer faktörlere bağlıdır. ${ }^{8}$ Anadolu'da meyvelerinin infüzyonu karminatif ve dijestif olarak iştah açmak için kullanılır. ${ }^{1,3}$ Kişniş tohum ve meyvelerinin antibakteriyel, antifungal, antienflamatuvar, antihelmentik, antioksidan, larvisidal, analjezik, anksiyolitik, antiaterojenik, antidiyabetik, antikarsinojenik, antiülserojenik, hepatoprotektif, kardiyoprotektif etkilerinin olduğu bilimsel çalışmalarda rapor edilmektedir. ${ }^{9-29}$

Bu çalışmada aktarlarda spazmolitik, gaz söktürücü veya iştah arttırıcı oldukları beyan edilerek satışı yapılan 12 kişniş örneği, Avrupa Farmakopesi 8.0'daki "Coriandri fructus" monografında belirlenen kriterler yönünden değerlendirilmiş ve bu tip ürünler açısından piyasa durum tespiti yapılmıştır.

\section{Materyal ve Yöntem}

\section{Bitki Örnekleri}

Analiz için 2018 yılı Şubat, Mart aylarında 12 farklı aktardan kişniş adıyla satın alınan numunelere numaralar verilerek Tablo 1'de satın alındıkları yerler gösterilmiştir.

\section{Avrupa Farmakopesi 8.0 Analizi $^{30}$}

Analiz yöntemleri için Avrupa Farmakopesi 8.0'da yer alan "Coriandri fructus" monografı kullanılmıştır. ${ }^{30}$ Aktardan alınan 12 farklı numune için morfolojik ve mikroskobik incelemeler, ince tabaka kromatografisi (ITK), uçucu yağ miktar tayini, yabancı madde, kurutmada kayıp ve total kül analizleri yapılmıştır. 
Tablo 1. Kişniş numunelerinin satın alındıkları yerler

\begin{tabular}{llll}
\hline $\begin{array}{l}\text { Numune } \\
\text { numarası }\end{array}$ & Alınan yer & $\begin{array}{l}\text { Numune } \\
\text { numarası }\end{array}$ & Alınan yer \\
\hline $\mathbf{1}$ & Fatih, Ankara & $\mathbf{7}$ & Narlıdere, İzmir \\
$\mathbf{2}$ & Sincan, Ankara & $\mathbf{8}$ & Çarşı, Isparta \\
$\mathbf{3}$ & Sincan, Ankara & $\mathbf{9}$ & Etimesgut, Ankara \\
$\mathbf{4}$ & Sincan, Ankara & $\mathbf{1 0}$ & Elvankent, Ankara \\
$\mathbf{5}$ & Sincan, Ankara & $\mathbf{1 1}$ & Elvankent, Ankara \\
$\mathbf{6}$ & Eryaman, Ankara & $\mathbf{1 2}$ & Etimesgut, Ankara \\
\hline
\end{tabular}

\section{Morfolojik analiz}

Aktardan alınan her bir numune Avrupa Farmakopesi 8.0 monografında yer alan genişlik, uzunluk, kalınlık, renk, şekil gibi morfolojik özellik ölçütleri açısından incelendi.

\section{Mikroskobik analiz}

Aktardan alınan numunelerden bir gram olacak şekilde havanda toz edildi. Reaktif olarak Kloralhidrat çözeltisi kullanıldı. Toz haline getirilen numuneler mikroskop kullanılarak incelendi.

\section{ITK}

Farmakopede belirtildiği gibi mukayese çözeltisi ve her bir numuneden hazırlanan test çözeltileri kullanıldı. Mukayese çözeltisini hazırlamak için $15 \mu \mathrm{l}$ linalol beş $\mathrm{ml}$ hekzan içinde çözüldü. Test çözeltileri için $500 \mathrm{mg}$ toz drog üzerine beş ml hekzan ilave edilip, üç dakika çalkalanıp, süzüldü. iTK'da sabit faz olarak silikajel 60F 254 dolgu materyali ile kaplanmıs plaklar, mobil faz olarak etil asetat/toluen (5:95 hacim/hacim) solvan sistemi kullanıldı. Analiz sonrasında plaklara Anisaldehit revelatörü püskürtülerek $100-105{ }^{\circ} \mathrm{C}$ de 10 dakika ısıtılarak oluşan renkler gözlemlendi.

\section{Yabancı madde analizi}

Numunelerinin her birinden $30 \mathrm{~g}$ tartıldı, daha sonra beyaz bir kağıt üzerine ince bir tabaka halinde yayıldı. Yabancı maddeler çıplak gözle incelendi, ayrılarak tartımı yapıldı ve yüzdesi hesaplandı.

\section{Uçucu yağ miktar tayini}

Toz edilmiş $30 \mathrm{~g}$ drog Clevenger cihazı kullanılarak iki saat boyunca su distilasyonu işlemine tabi tutuldu. Distilasyon süresi sonunda cihaz soğumaya bırakıldı. Soğuma işleminden sonra dereceli kısımdan uçucu yağ miktarı ölçülerek miktar tayini yapıldı, sonuçlar \% (hacim/ağılık) cinsinden ifade edildi.

\section{Kurutmada kayıp}

Etüvde ısıtılarak sabit ağılığa getirilmiş ve darası alınmış cam kapaklı tartı kaplarının içine her numuneden bir gram olacak şekilde toz edildi. Etüvde $105^{\circ} \mathrm{C}$ 'de 120 dakika kurutuldu. Daha sonra desikatöre alınarak, soğutuldu ve tartıldı. İşlemlere sabit ağırlığa gelinceye kadar devam edildi. Numunelerde \% (ağılık/ağırlık) cinsinden nem miktar tayini hesaplandı. Bütün numuneler için deney üç kez tekrarlandı ve sonuçların ortalaması alındı.

\section{Total kül miktar tayini}

Sabit ağırlığa getirilmiş krozelerin içine toz edilmiş numune bir gram olacak şekilde tartıldı. $600^{\circ} \mathrm{C}^{\prime}$ lik fırında yakma işlemi gerçekleştirildi. Fırından çıkartılıp desikatöre alındı, soğutuldu ve tartıldı. Sabit ağırlığa gelinceye kadar işleme devam edildi. Numunelerde \% (ağırlık/ağırlık) cinsinden kül miktarları hesaplandı. Bütün numuneler için deney üç kez tekrarlandı ve sonuçların ortalaması alındı. 


\section{İstatistiksel analiz}

Deneyler sonucu bulunan değerlerin standart hata (S.H) değerlerini hesaplayabilmek için GraphPad Software Instat programı kullanılmıştır. Ortalama S.H değeri hesaplanan çalışmalar için en az üç deneyin sonuçları kullanıımıştır.

\section{Bulgular}

\section{Morfolojik analiz}

Aktardan alınan 12 farklı numunenin genişlik ve uzunluk ölçümleri sonucunda bulunan değerler Tablo 2 'de gösterilmiştir. Numunelerin genişliklerinin 1,67-3,78 mm., uzunluklarının da 2,73-5,29 mm. arasında değiştikleri tespit edilmiştir (Tablo 2).

\begin{tabular}{lll}
\multicolumn{3}{l}{ Tablo 2. Kişniş numunelerinin genişlik ve uzunlukları } \\
\hline $\begin{array}{ll}\text { Numune } \\
\text { numarası }\end{array}$ & $\begin{array}{l}\text { Genişlik } \\
\text { (En kü̈cük-En büyük, mm) }\end{array}$ & $\begin{array}{l}\text { Uzunluk } \\
\text { (En küçük-En büyük, mm) }\end{array}$ \\
\hline $\mathbf{1}$ & $1,72-2,31$ & $2,76-4,22$ \\
$\mathbf{2}$ & $2,17-3,21$ & $3,72-5,12$ \\
$\mathbf{3}$ & $1,82-2,48$ & $2,91-4,17$ \\
$\mathbf{4}$ & $1,76-2,81$ & $3,12-4,93$ \\
$\mathbf{5}$ & $1,84-2,79$ & $3,23-5,29$ \\
$\mathbf{6}$ & $2,03-3,54$ & $2,73-4,63$ \\
$\mathbf{7}$ & $2,23-3,28$ & $2,82-3,81$ \\
$\mathbf{8}$ & $1,69-3,02$ & $3,26-5,15$ \\
$\mathbf{9}$ & $1,72-3,62$ & $3,18-4,91$ \\
$\mathbf{1 0}$ & $1,89-3,04$ & $3,22-4,28$ \\
$\mathbf{1 1}$ & $1,92-3,21$ & $3,54-4,71$ \\
$\mathbf{1 2}$ & $1,67-3,78$ & $3,12-4,27$ \\
\hline
\end{tabular}

\section{Mikroskobik analiz}

Yapılan mikroskobik analizde endosperma parçaları; mikrokürecikler; yağ damlaları; taş hücrelerinden oluşan endokarp parçaları; salgı kanalları; çok yüzlü hücrelerden oluşan epikarp parçaları; kısa, kalınlaşmış, fusiform hücrelerden oluşan mezokarpın sklerankima tabakası parçaları; kalsiyum okzalat kristalleri; iletim demeti parçaları; stoma içeren epikarp parçaları tespit edilmiştir.

\section{ITK}

Aktarlardan alınan kişniş numunelerinde hazırlanan ekstrelerde, Avrupa Farmakopesi 8.0’a göre referans olarak kullanılan linalole ait menekşe renkli lekeler tüm numunelerde görülmüştür (Şekil 1).

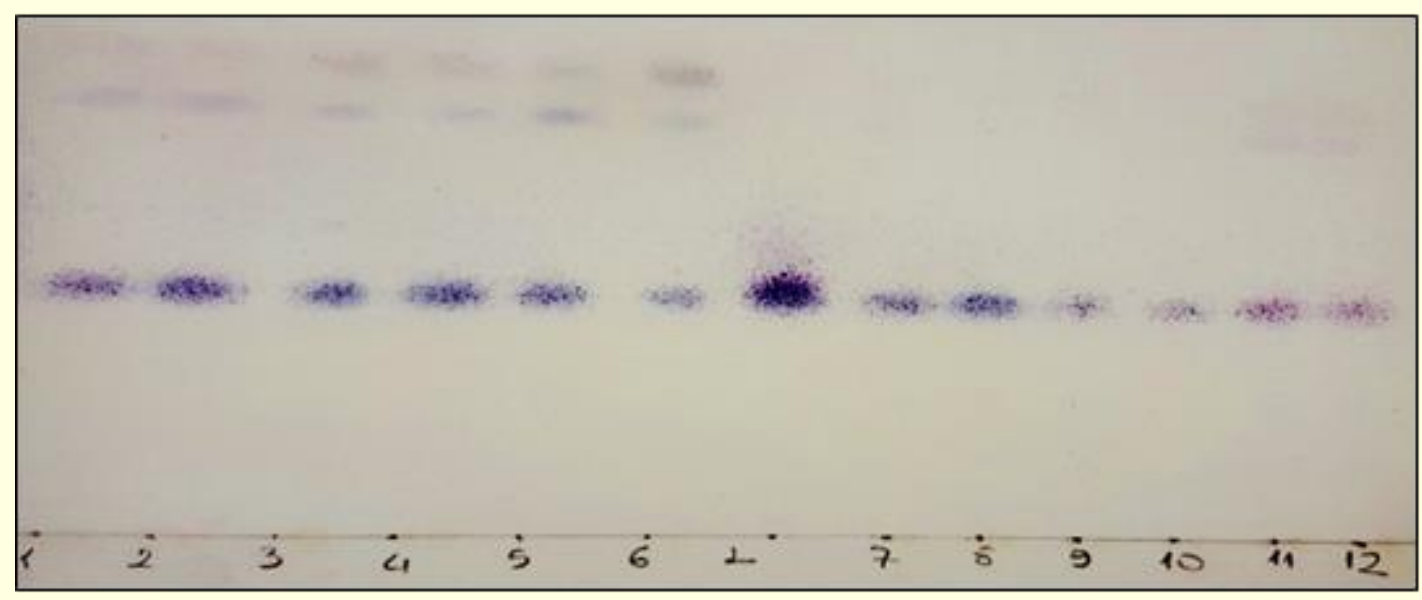

Şekil 1. Kişniş numunelerinden hazırlanan ekstrelerin ince tabaka kromatogramı (L: Linalol) 


\section{Yabancı madde}

Makroskobik analiz sonuçlarına göre 3 ve 4 numaralı kişniş numunelerinin haricindeki diğer tüm kişniş numunelerinin kremokarplarında delikler görülmüştür. Bazı kişniş numunelerinin kremokarplarında görülen delik görünümleri Şsekil $\mathbf{2}^{\prime}$ de sunulmuştur.
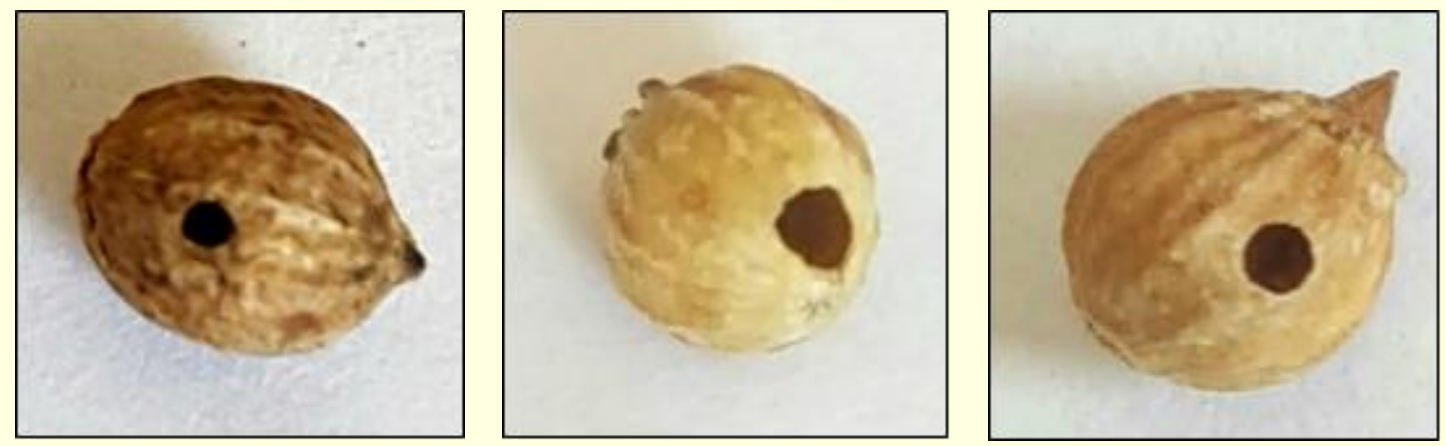

Şekil 2. Kişniş numunelerinin kremokarplarında görülen delikler

Ayrıca kişniş numunelerinin içerdiği yabancı maddeler ayrılıp tartılmış ve daha sonra yabancı madde miktarı hesaplanmıştır. Numunelerin yabancı madde miktarlarının \%0,23-3,46 (ağırlık/ağırlık) arasında değiştiği görülmüştür. Kişniş numunelerine ait yabancı madde miktarları Tablo $\mathbf{3}$ 'de gösterilmiştir. Numunelerde bitkiye ait sap ve dallar, rezene gibi droglara ait meyve parçaları, larva kılıfı gibi kirliliklerin olduğu da tespit edilmiştir.

Tablo 3. Kişniş numunelerine ait yabancı madde miktarları

\begin{tabular}{llll}
\hline $\begin{array}{l}\text { Numune } \\
\text { numarası }\end{array}$ & $\begin{array}{l}\text { Yabancı madde } \\
\text { miktarı }(\% \text { a/a) }\end{array}$ & $\begin{array}{l}\text { Numune } \\
\text { numarası }\end{array}$ & $\begin{array}{l}\text { Yabancı madde } \\
\text { miktarı }(\% \text { a/a) }\end{array}$ \\
\hline $\mathbf{1}$ & 3,46 & $\mathbf{7}$ & 1,71 \\
$\mathbf{2}$ & 0,59 & $\mathbf{8}$ & 1,58 \\
$\mathbf{3}$ & 1,92 & $\mathbf{9}$ & 1,10 \\
$\mathbf{4}$ & 0,58 & $\mathbf{1 0}$ & 0,46 \\
$\mathbf{5}$ & 0,23 & $\mathbf{1 1}$ & 0,95 \\
$\mathbf{6}$ & 0,80 & $\mathbf{1 2}$ & 2,27 \\
\hline
\end{tabular}

\section{Uçucu yağ miktar tayini}

Tüm kişniş numunelerinin uçucu yağ miktarları analiz edilmiş ve numunelerin uçucu yağ miktarları $\mathrm{ml} / \mathrm{kg}$ drog cinsinden $1,0 \pm 0,1-10,8 \pm 0,5$ değerleri arasında olduğu bulunmuştur. Uçucu yağ miktarının en yüksek, numune $5\left(10,8 \pm 0,5 \mathrm{ml} / \mathrm{kg}\right.$ drog) en düşük olarak, numune 8 ve numune $10^{\prime} \mathrm{da}(1,0 \pm 0,1 \mathrm{ml} / \mathrm{kg}$ drog ) olduğu tespit edilmiştir (Tablo 4).

\section{Kurutmada kayıp}

Avrupa Farmakopesi 8.0' da kişniş meyvelerinin kurutmada kayıp miktarının en yüksek \%10 olması gerektiği belirtilmiştir. ${ }^{30}$ Analiz sonucuna göre kişniş numunelerinin kurutmada kayıp miktarı \%5,82 $\pm 0,03$ $\% 7,89 \pm 0,08$ değerleri arasında olduğu bulunmuştur. Kurutmada kayıp miktarı en düşük, numune $1^{\prime}$ de

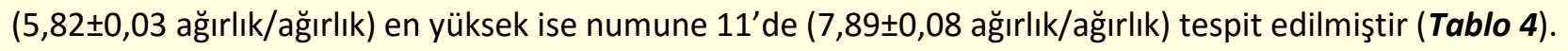

\section{Total kül miktar tayini}

Avrupa Farmakopesi 8.0, kişniş meyvelerinin kül miktarının \%8'i geçmemesi gerektiğini belirtir. ${ }^{30}$ Analiz

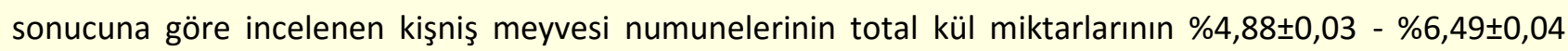
değerleri arasında olduğu tespit edilmiştir. Kül miktarı en düşük, numune $5^{\prime}$ te $(4,88 \pm 0,03)$ en yüksek ise numune $11^{\prime}$ de $(6,49 \pm 0,04)$ bulunmuştur (Tablo 4). 
Tablo 4. Kişniş numunelerinin uçucu yağ, kurutmada kayıp ve kül miktarları

\begin{tabular}{llll}
\hline $\begin{array}{l}\text { Numune } \\
\text { no }\end{array}$ & $\begin{array}{l}\text { Uçucu yağ miktarı } \\
\mathbf{m l} / \mathbf{k g} \pm \text { S.H }\end{array}$ & $\begin{array}{l}\text { Kurutmada kayıp } \\
\% \mathrm{a} / \mathrm{a} \pm \mathbf{S} . \mathbf{H}\end{array}$ & $\begin{array}{l}\text { Kül miktarı } \\
\% \mathrm{a} / \mathrm{a} \pm \mathbf{S} . \mathbf{H}\end{array}$ \\
\hline $\mathbf{1}$ & $1,3 \pm 0,4$ & $5,82 \pm 0,03$ & $6,13 \pm 0,06$ \\
$\mathbf{2}$ & $1,9 \pm 0,2$ & $6,12 \pm 0,01$ & $5,64 \pm 0,05$ \\
$\mathbf{3}$ & $1,8 \pm 0,3$ & $6,46 \pm 0,02$ & $5,65 \pm 0,06$ \\
$\mathbf{4}$ & $2,7 \pm 0,5$ & $6,58 \pm 0,02$ & $5,33 \pm 0,09$ \\
$\mathbf{5}$ & $10,8 \pm 0,5$ & $7,24 \pm 0,02$ & $4,88 \pm 0,03$ \\
$\mathbf{6}$ & $1,5 \pm 0,1$ & $7,20 \pm 0,04$ & $5,46 \pm 0,03$ \\
$\mathbf{7}$ & $1,6 \pm 0,2$ & $7,08 \pm 0,11$ & $6,23 \pm 0,03$ \\
$\mathbf{8}$ & $1,0 \pm 0,1$ & $6,85 \pm 0,12$ & $6,44 \pm 0,06$ \\
$\mathbf{9}$ & $1,6 \pm 0,2$ & $6,52 \pm 0,30$ & $6,20 \pm 0,02$ \\
$\mathbf{1 0}$ & $1,0 \pm 0,1$ & $7,59 \pm 0,09$ & $5,43 \pm 0,04$ \\
$\mathbf{1 1}$ & $5,1 \pm 0,5$ & $7,89 \pm 0,08$ & $6,49 \pm 0,04$ \\
$\mathbf{1 2}$ & $8,3 \pm 0,2$ & $7,68 \pm 0,06$ & $5,40 \pm 0,05$ \\
\hline
\end{tabular}

* a/a: ağırlık/ağırlık, S.H: Ortalama standart hata

Numunelere ait tüm analiz sonuçları, Avrupa Farmakopesi'ne uygun olup olmadıklarının daha net görülmesi açısından Tablo 5 'te toplu olarak özetlenmiştir.

Tablo 5. Kişniş numunelerinin Avrupa Farmakopesi 8.0'a göre analiz sonuçlarının değerlendirilmesi

\begin{tabular}{|c|c|c|c|c|c|c|c|c|}
\hline $\begin{array}{l}\text { Numune } \\
\text { numarası }\end{array}$ & $\begin{array}{l}\text { Morfolojik } \\
\text { analiz } \\
\text { uygunluğu }\end{array}$ & $\begin{array}{l}\text { Mikroskobik } \\
\text { analiz } \\
\text { uygunluğu }\end{array}$ & $\begin{array}{l}\text { iTK } \\
\text { uygunluğu }\end{array}$ & $\begin{array}{l}\text { Yabancı } \\
\text { madde } \\
\text { uygunluğu }\end{array}$ & $\begin{array}{l}\text { Uçucu yağ } \\
\text { miktar } \\
\text { uygunluğu }\end{array}$ & $\begin{array}{l}\text { Kurutmada } \\
\text { kayıp miktar } \\
\text { uygunluğu }\end{array}$ & $\begin{array}{l}\text { Total kül } \\
\text { miktar } \\
\text { uygunluğu }\end{array}$ & $\begin{array}{l}\text { Avrupa } \\
\text { Farmakopesi'ne } \\
\text { göre sonuç }\end{array}$ \\
\hline 1 & + & + & + & - & - & + & + & Uygun değil \\
\hline 2 & + & + & + & - & - & + & + & Uygun değil \\
\hline 3 & + & + & + & + & - & + & + & Uygun değil \\
\hline 4 & + & + & + & + & - & + & + & Uygun değil \\
\hline 5 & + & + & + & - & + & + & + & Uygun değil \\
\hline 6 & + & + & + & - & - & + & + & Uygun değil \\
\hline 7 & + & + & + & - & - & + & + & Uygun değil \\
\hline 8 & + & + & + & - & - & + & + & Uygun değil \\
\hline 9 & + & + & + & - & - & + & + & Uygun değil \\
\hline 10 & + & + & + & - & - & + & + & Uygun değil \\
\hline 11 & + & + & + & - & + & + & + & Uygun değil \\
\hline 12 & + & + & + & - & + & + & + & Uygun değil \\
\hline
\end{tabular}

,+ Uygun; -,Uygun değil

\section{Tartışma}

Avrupa Farmakopesi'nde kişniş meyvesinin kahverengi veya açık kahverengi, küreye benzer şekilde, yaklaşık 1,5-5 mm çapında ve 2-6 mm uzunluğunda olduğu bildirilmiştir. ${ }^{30}$ Yapılan morfolojik analizler sonucunda numunelerin en ve boy uzunluklarının, genel görünümlerinin Avrupa Farmakopesi'ne uygun olduğu görülmüştür.

Temin edilen bütün numunelerin Avrupa Farmakopesi'nde belirtilen doku elementleri yönünden mikroskobik incelemeleri yapılmıştır. Analiz sonucunda olması beklenen mikrokürecikler, yağ damlası, epikarp parçaları ve kalsiyum okzalat kristalleri, salgı kanalları, mezokarpın sklerenkima parçaları, iletim demetleri, endokarp altındaki mezokarpın dikdörtgen biçimindeki sklereitleri, taş hücrelerinden oluşan endokarp parçaları ve stoma içeren epikarp tüm numunelerde görülmüştür. ${ }^{30}$

ITK ile kişniş meyvelerinden hazırlanan hekzan ekstreleri referans olarak kullanılan linalolle karşılaştırılmıştır. ${ }^{30}$ Tüm numunelerin linalol içerdiği tespit edilmiştir.

Avrupa Farmakopesi'ne göre yabancı madde tayininde kremokarplarda böcek kaynaklı deliklerin görülmesi istenmemektedir. ${ }^{30}$ Yapılan analiz sonucunda numune 3 ve numune 4 dışındaki tüm numunelerde kremokarplarda böceklerden kaynaklandığı düşünülen delikler görülmüştür. Numune 3 ve numune 4 
dışındaki diğer numunelerin Avrupa Farmakopesi'nde belirtilen yabancı madde tayin kriterlerine uygun olmadığı görülmüştür.

Avrupa Farmakopesi'ne göre kişniş meyvelerinin bir kilogramında minimum üç $\mathrm{ml}$ uçucu yağ bulunması istenmektedir. ${ }^{30}$ Analiz sonuçlarına göre numune 5, numune 11 ve numune 12 haricindeki örneklerin uçucu yağ miktarları farmakopede istenen limitleri karşılamamıştır. Bu durum limitleri karşılamayan numunelerin uygun saklama koşulları altında depolanmadığını ve çok bekletildiğini göstermektedir. Uçucu yağ miktarları yönünden numune 5 , numune 11 ve numune 12 uygun bulunmuştur.

Avrupa Farmakopesi'nde kişniş meyvelerinde kurutmada kayıp analizi yapılması istenen fizikokimyasal bir analizdir. Farmakopede kişniş numunelerinde kurutmada kayıp miktarının \%10'u geçmemesi gerektiği belirtilmektedir. ${ }^{30}$ Analiz sonucunda tüm numunelerin kurutmada kayıp miktarı açısından farmakopeye uygunluk gösterdiği tespit edilmiştir. Kurutmada kayıp miktarı en az numune 1'de, en fazla ise numune $11^{\prime}$ de tespit edilmiştir. Bu sonuçlar incelenen numunelerin kurutulma, taşınma ve depolanma işlemlerinde rutubete maruz kalmadıklarını göstermektedir.

Yine Farmakopeye göre kişniş meyvelerinin total kül miktarının \%8'i geçmemesi gerekmektedir. ${ }^{30}$ Analiz sonucunda tüm numunelerin kül miktarlarının farmakopeye uygun olduğu tespit edilmiştir. Bu durum numunelerde taş, toprak, metal vb. inorganik kirliliklerin olmadığını göstermiştir. Total kül miktarı en az numune 5 'te, en fazla numune 11 'de bulunmuştur.

Kişniş tıbbi amaçla ve baharat olarak kullanılmaktadır. Antiepileptik, antidepresan, antienflematuvar, antidislipidemik, antihipertansif, nöroprotektif, diüretik etkileri bilimsel çalışmalarla tespit edilmiştir. ${ }^{1}$ Halk hekimliğinde sindirim bozukluklarına karşı gaz giderici, spazmolitik, ayrıca antimikrobiyal olarak ve iştahı artırmak için kullanıldığı bilinmektedir. ${ }^{7}$ Meyvelerinden taze hazırlanan çaylar yemeklerden hemen sonra gastrointestinal sistemdeki gaz problemleri için tüketilir. ${ }^{31}$ Meyvelerin stomaşik, spazmolitik, karminatif, antibakteriyel ve antifungal etkilerinden uçucu yağ içeriklerinin sorumlu olduğu bilinmektedir. ${ }^{32}$

Sindirim uyarııı etkisi kapsamlı çalışmalarla doğrulanmıştır. Buna göre kişniş meyveleri karaciğeri daha fazla safra salgılamak için uyarır, pankreas ve bağırsak kaynaklı sindirim enzimleri uyarılarak besinlerin sindirimi kolaylaştırılır. Safra salgısının ve sindirim enzimlerinin aktivitelerinin uyarılması, genel sindirim sürecini hızlandırarak, gıdanın gastrointestinal sistemden geçiş süresinde önemli bir azalmaya yol açmaktadır. ${ }^{7,33}$

Jabeen ve ark. izole sıçan jejenumunda yapmış oldukları çalışmada kişniş meyve ekstrelerinin kalsiyum kanallarında inhibisyon oluşturarak spazmolitik etkiler oluşturduğunu tespit etmişlerdir. ${ }^{34}$

Kişniş meyvelerinden elde edilen uçucu yağlarla yapılan çalışmalarda, Bacillus cereus, Enterococcus faecalis, Staphylococcus aureus, Pseudomonas aeruginosa, Klebsiella pneumoniae, Escherichia coli, Salmonella typhi ve Acinetobacter baumannii suşlarına karşı farklı seviyelerde antibakteriyel etkiler tespit edilmiştir. ${ }^{11,35}$ Matasyoh ve ark. yaptıkları çalışmada, Kenya'da yetişen kişniş meyvelerinden elde edilen uçucu yağın Gram pozitif bakterilerden S. aureus, Bacillus spp. ve Gram negatif bakterilerden E. coli, Salmonella typhi, $K$. pneumoniae, Proteus mirabilis, $P$. aeruginosa klinik izolatlarına karşı etkili olduğunu rapor etmişlerdir. ${ }^{36}$ Abascal ve ark. kişniş uçucu yağının S. aureus, S. haemolyticus, P. aeruginosa, E. coli ve Listeria monocytogenes karşı güçlü antimikrobiyal etkiler gösterdiklerini tespit etmişlerdir. ${ }^{37}$ Kişniş meyvelerinden ve yapraklarından elde edilen uçucu yağların ve uçucu olmayan bileşikleri içeren ekstrelerin 1,1-difenil-2pikrilhidrazil (DPPH) serbest radikalini temizleme aktiviteleri ve demir indirgeyici antioksidan gücü gibi antioksidan aktivitelere sahip oldukları tespit edilmiştir. ${ }^{38,39}$ Kişniş uçucu yağının diğer bazı uçucu yağlarla, DPPH radikalini temizleme potansiyelleri karşılaştıııldığında bu uçucu yağın en yüksek antioksidan aktiviteye sahip olduğu gösterilmiştir. Bu yağlar arasında etki büyükten küçüğe olacak şekilde şu şekilde sıralanmıştır; kişniş> çörek otu> pamuk tohumu> yer fıstığı> keten tohumu> zeytin. ${ }^{40}$ Wangensteen ve ark. kişniş meyve 
uçucu yağının DPPH radikalini temizleme aktivitesinin kişniş yapraklarından daha yüksek olduğunu bulmuşlardır. Meyvelerin uçucu yağının antioksidan aktivitesinin, yaprak uçucu yağına kıyasla daha güçlü olmasının sebebi olarak yüksek konsantrasyonda linalol taşıması olduğu rapor edilmiştir. ${ }^{15}$

Sonuç olarak, kremokarplarda görülen delikler, bazı numunelerin böceklendiğine işaret etmektedir. Numunelerde meyve dışında bitkiye ait sap ve dallar, rezene gibi droglara ait meyve parçaları, larva kılıfı gibi kirliliklerin de tespit edilmesi kişniş numunelerinin toplanma ve depolanma sırasında da istenmeyen kirliliklerle kontamine olduğunu göstermiştir. Ayrıca bu numunelerin çay olarak hazırlanmaları ile etkiden sorumlu olan uçucu yağın miktar açısından yetersiz olduğu düşünüldüğünde; gaz, dispepsi, iştahsızlık gibi şikayetlerde ve antimikrobiyal ve antioksidan etkinlik için herhangi bir aktivite gösteremeyeceği sonucuna varılmıştır.

\section{Sonuç}

Ülkemizde 12 farklı aktardan kişniş adıyla satın alınan numunelere Avrupa Farmakopesi 8.0'da bulunan "Coriandri fructus" monografında belirtilen analizler uygulanmıştır. Analizler sonucunda halk arasında birçok rahatsızlığa karşı kullanılan kişnişi temin etmek üzere başvurulan aktarlardan bu kalite özellikleri ile kullanılmasının toplum sağlığı açısından risk teşkil ettiği sonucuna varılmıştır. Dolayısıyla aktar ve baharat dükkanlarında satılan bu numunelerin tıbbi amaçlarla kullanılmaması gerektiği zaten tartışılması gereksiz bir durum olup, analiz sonuçlarına göre baharat olarak bile bu ürünlere aktarlardan ulaşmanın ne kadar sağlıksız olacağı görülmüştür.

Halen aktar ve benzeri dükkanlarda, satış yapan personel tarafından bu tip ürünlerin endikasyonları hakkında bilgiler verilmektedir. Bu bağlamda, uygun kalite kriterlerine sahip bitkisel ürünlerin eczanelerde ve hekim önerisi ile insanlara ulaştırıması ve sözü edilen satışı yapılan yerlerde denetimlerin arttırılması, toplum sağlığı açısından baharat olarak kullanımı dışında herhangi bir endikasyon beklentisi ile temin edilmek istenen bu ürünlere eczaneler dışındaki bir yerden ulaşılmaması için toplumun bilinçlendirilmesi gerekmektedir.

\section{Bilgi}

Çalışma 9-12 Nisan 2018 tarihinde Titanic Beach Hotel Lara-Antalya'da düzenlenen XXIII. Bitkisel Ilaç Hammadeleri Toplantısı'nda (BIHAT 2018) sunulmuştur. Çalışma sırasında herhangi bir firma veya kurumdan hiçbir maddi destek alınmamıştır. Çıkar çatışması olmadığını beyan ederiz.

\section{Araştırmacı Katkı Oranı Beyanı}

Erek Ulutaş: Denetleme/danışmanlık, veri toplama veya işleme, analiz veya yorum, kaynak taraması, makalenin yazımı, eleştirel inceleme.

Semih Bulut: Veri toplama veya işleme, kaynak taraması, makalenin yazımı, eleştirel inceleme.

Didem Deliorman Orhan: Fikir/kavram, tasarım, denetleme/danışmanlık, analiz veya yorum, eleştirel inceleme.

\section{Kaynaklar}

1. Sahib NG, et al. Coriander (Coriandrum sativum L.): A potential source of high-value components for functional foods and nutraceuticals-a review. Phytother Res 2013;27(10):1439-1456.

2. Diederichsen A. Coriander (Coriandrum sativum L.) promoting the conservation and use of underutilized and neglected crops. Institute of Plant Genetics and Crop Plant Research, Gatersleben/International Plant Genetic Resources Institute, Rome;1996. pp:8-26.

3. Tubives.com [Internet]: Coriandrum sativum, Turkish plants data service. [cited 2021 March 2]. Available from: http://www.tubives.com/

4. Deniz EU, et al. Kişniş (Coriandrum sativum L.) üzerine bir derleme. Marmara Pharm J 2018;22(1): 15-28.

5. Tanker N, Koyuncu M, Coşkun M. Farmasötik Botanik. 5.baskı. Ankara: Ankara Üniversitesi Basımevi; 2016. pp:251-252. 
6. Sriti J, et al. Lipid, fatty acid and tocol distribution of coriander fruit's different parts. Ind Crop Prod 2010;31(2):294-300.

7. Laribi B, et al. Coriander (Coriandrum sativum L.) and its bioactive constituents. Fitoterapia 2015;103:9-26.

8. Wei JN, et al. Phytochemical and bioactive profile of Coriandrum sativum L. Food Chem 2019; 286:260-267.

9. Mahdi OS. Evaluation of inhibitory activity of extracts of Apium gravelens, Coriandrum sativum and Cuminum cyminum against number of pathogenic bacteria. Kufa J Vet Sci 2011;2(2):37-50.

10. Casetti $F$, et al. Antimicrobial activity against bacteria with dermatological relevance and skin tolerance of the essential oil from Coriandrum sativum L. fruits. Phytother Res 2012;26(3):420-424.

11. Soares BV, et al. Antifungal activity, toxicity and chemical composition of the essential oil of Coriandrum sativum L. fruits. Molecules 2012;17(7):8439-8448.

12. Zhang CR, et al. Evaluation of coriander spice as a functional food by using in vitro bioassays. Food Chem 2015:167:24-29.

13. Eguale $\mathrm{T}$, et al. In vitro and In vivo anthelmintic activity of crude extracts of Coriandrum sativum against Haemonchus contortus. J Ethnopharmacol 2007;110(3):428-433.

14. Yepez B, et al. Producing antioxidant fractions from herbaceous matrices by supercritical fluid extraction. Fluid Ph Equilibria 2002;194-197:879-884.

15. Wangensteen H, Samuelsen AB, Malterud KE. Antioxidant activity in extracts from coriander. Food Chem 2004;88(2):293-297.

16. Msaada K, et al. Antioxidant activity of methanolic extracts from three coriander (Coriandrum sativum L.) fruit varieties. Arab J Chem 2017;10(2):3176-3183.

17. Benelli G, et al. Larvicidal and repellent activity of the essential oil of Coriandrum sativum L. (Apiaceae) fruits against the filariasis vector Aedes albopictus skuse (Diptera: Culicidae). Parasitol Res 2013;112(3):1155-1161.

18. Pathan AR, Kothawade KA, Logade MN. Anxiolytic and analgesic effect of seeds of Coriandrum sativum Linn. Int J Res Pharm Chem 2011;1(4): 1087-1099.

19. Emamghoreishi M, Khasaki M, Aazam MF. Coriandrum sativum: evaluation of its anxiolytic effect in the elevated plus-maze. J Ethnopharmacol 2005;96(3):365-370.

20. Patel D, et al. Coriandrum sativum L. seed extract mitigates lipotoxicity in Raw 264.7 cells and prevents atherogenic changes in rats. Excli J 2013;12:313-334.

21. Chithra V, Leelamma S. Coriandrum sativum- mechanism of hypoglycemic action. Food Chem 1999;67(3):229-231.

22. Eidi M, Eidi A. Effect of Coriander (Coriandrum sativum L.) seed ethanol extract in experimental diabetes. Preedy VR, Watson RS, Patel VB editors. Nuts and seeds in health and disease prevention. Academic Press; 2011. pp:395-400.

23. Aissaoui A, et al. Hypoglycemic and hypolipidemic effects of Coriandrum sativum L. in Meriones shawi rats. J Ethnopharmacol 2011;137(1):652-661.

24. Naquvi KJ, Ali M, Ahamad AJ. Antidiabetic activity of aqueous extract of Coriandrum sativum L. fruits in streptozotocininduced rats. Int J Pharm Pharm Sci 2012;4(1):239-240.

25. Waheed A, et al. Clinical investigation of hypoglycemic effect of Coriandrum sativum in type-2 (NIDDM) diabetic patients. Pakistan J P 2006;23(1):7-11.

26. Chithra V, Leelamma S. Coriandrum sativum- effect on lipid metabolism in 1,2-dimethyl hydrazine-induced colon cancer. J Ethnopharmacol 2000;71(3):457-463.

27. Al-Mofleh IA, et al. Protection of gastric mucosal damage by Coriandrum sativum L. pretreatment in Wistar albino rats. Environ Toxicol Pharmacol 2006;22(1):64-69.

28. Anilakumar KR, Nagaraj NS, Santhanam K. Effect of coriander seeds on hexachlorocyclohexane-induced lipid peroxidation in rat liver. Nutr Res 2001;21(11):1455-1462.

29. Patel DK, et al. Cardioprotective effect of Coriandrum sativum L. on isoproterenol induced myocardial necrosis in rats. Food Chem Toxicol 2012;50(9):3120-3125.

30. Council of Europe (EDQM). Coriander, Coriandri fructus. European Pharmacopoeia 8.0. 2013:1220-1221.

31. Herbsetc.com [Internet]. The medicinal properties of coriander. [cited 2021 March 3]. Available from: https://www.herbsetc.com/content/PDF/Coriander_article_2017.pdf

32. Bisset G. Coriandri fructus, herbal drugs and phytopharmaceuticals. A handbook for practice on a scientific basis. Stuttgart: CRC Press; 1994. pp:159-160.

33. Platel K, Srinivasan K. Digestive stimulant action of spices: a myth or reality? Indian J Med Res 2004;119(5):167-179.

34. Jabeen $Q$, et al. Coriander fruit exhibits gut modulatory, blood pressure lowering and diuretic activities. J Ethnopharmacol 2009;122(1):123-130.

35. Alves-Silva JM, et al. Chemical composition and in vitro antimicrobial, antifungal and antioxidant properties of essential oils obtained from some herbs widely used in Portugal. Food Control 2013;32(2):371-378.

36. Matasyoh JC, et al. Chemical composition and antimicrobial activity of the essential oil of Coriandrum sativum. Food Chem 2009;113(2):526-529.

37. Abascal K, Yarnell E. Cilantro-Culinary herb or miracle medicinal plant? Altern Complement Ther 2012;18(5):259-264. 
38. El-Ghorab A, Shibamoto T, Özcan MM. Chemical composition and antioxidant activities of buds and leaves of capers (Capparis ovata Desf. var. canescens) cultivated in Turkey. J Essent Oil Res 2007;19(1):72-77.

39. Shahwar MK, et al. Characterization of coriander (Coriandrum sativum L.) seeds and leaves: volatile and non volatile extracts. Int J food prop 2012;15(4):736-747.

40. Ramadan MF, Moersel JT. Screening of the antiradical action of vegetable oils. J Food Compos Anal 2006;19(8):838-842. 